\title{
TEACHER PEDAGOGICAL COMPETENCIES IN INCLUSIVE
}

\section{ELEMENTARY SCHOOL}

\author{
RUWAIDA ZAFIRA ${ }^{1}$ \& GANES GUNANSYAH ${ }^{2}$ \\ ${ }^{I}$ Education Department, Tsukuba University, Japan \\ ${ }^{2}$ Faculty of Education, Universitas Negeri Surabaya, Indonesia
}

\begin{abstract}
Pedagogical competence is the ability to teach the students in the entire learning process. This competence could be seen from three main things that are how the teacher planning, managing and assessing the learning process. Different personality and ability among the students require teacher capable fulfilling all students' needs through inclusive setting. This is prominent since inclusive setting become an education standard in all region in Indonesia. Both academic and nonacademic skills of the SWDs students should be met to align it with the aim of inclusive education that is the education for all. The purpose of this research is to know the teacher's pedagogical competence for SWDs students in the inclusive elementary school of Klampis Ngasem 1 Surabaya. This research used a qualitative approach with a descriptive method which describes ten indicators of pedagogical competence of the teachers dealing with the SWDs students in every inclusive class in Klampis Ngasem elementary school 1 Surabaya. The researcher used three types of a qualitative research study of documentation or text, observation, and the interview. Data analysis used is the data reduction, data display, and conclusion. The result showed that the teacher who had a primary education background and teaching experience met the indicators of teacher's pedagogical competence. Evidenced by nine out of ten indicators met in the category one which consists of the teacher with a primary education background and teacher with teaching experience for 21 years. For category two which consist of the teacher who graduated from non-primary education background only fulfilled four out of ten indicators. This research also proves the theory which states the competence of professional teacher is based on the teacher's skill, teaching experience, and the teacher's educational background. These three aspects hold an essential role in forming the teachers' pedagogical competence.
\end{abstract}

KEYWORDS: Pedagogical competence, Inclusive education \& SWDs student

Received: Mar 16, 2018; Accepted: Apr 06, 2018; Published: May 17, 2018; Paper Id.: IJESRJUN201813

\section{INTRODUCTION}

Every level of education has its national standard of education (Standard Nasional Pendidikan (SNP)) which has to be achieved on a succession of education. One of eight of SNP is standard of teachers; it regulates the competency of the teacher on running the education. In based on the regulation of Indonesian ministry of education no. 16 the year 2007 regarding the standard of academic qualifications and teacher competency article 1 that every teacher should be qualified according to the national standard. Firmly stated that there are four companies the teachers should have the basis of the learning process. The four competencies are pedagogy, personality, professional, and social (article 28 clause 3 government regulation no. 19 the year 2005 regarding the national standard of education).

In the regulation no. 14 the year 2005 regarding teachers and lectures, again stated that pedagogy 
competency is "the ability to control the students learning processes." Depdiknas (2004) call this competency as " the management learning competency." This competency can be seen from the ability to set a plan on the learning process, the capability of doing interactions or managing of the learning process, and giving feedback on student performances.

Capability and personality of students are exactly different. Therefore, teachers are demanded to possess the management skills of the learning process from planning, execution, until evaluation in the appropriate manner to create a high quality of next Indonesian generation. This is not only for regular schools, but also it should be applied in inclusive schools. In general speaking, not every student with various backgrounds in inclusive schools can attend the learning process generally in class. SWDs with diverse categories form blind, deaf, autism, mute, mentally disabled, and the slow learner has a significant potential to have a standard education and self-development according to their capabilities, needs, and talents. Thus, those should be handled by qualified teachers.

The emergence of the Inclusive education concept in 2007 was preceded by the declaration of "Indonesia towards Inclusive Education" in 2004, enabling the government to enforce education for all in every educational level by generalizing the provision of open and friendly educational services to every learner without any distinction and discrimination, bringing together SWDs and regular students in the same school and class. This is based on Law No.20 / 2003 on the National Education System which states that "education services for SWDs have been regulated by government in the form of inclusive schools (Diknas, UU-RI. /2003). It is affirmed by the circular letter of the Directorate of Primary and Secondary Education, Ministry of Education No.380 / C. C6 / MN / 2003 dated January 20, 2003, that "every district/city is required to conduct and develop inclusive education in at least 4 (four) schools consisting of elementary, junior, high/vocational school". This is the basis of every region, including Surabaya to improve as an inclusive city/district. Surabaya tries to accomplish it in every level of education, especially primary education. The acceptance of an inclusive educational award on December 3, 2014, in Temanggung, Yogyakarta, is proving that Surabaya, the first inclusive city in Indonesia, can create a friendly and open inclusive education. Based on information from Public Relations Dispendik Surabaya, "Surabaya does not need a declaration because what we do is already inclusive" (Eko, 2015). The fact that Surabaya without declaration has become the first inclusive city in Indonesia, which always try to provide inclusive services at every level of education.

Surabaya's primary education level is spread over 50 inclusive schools. In general, according to data from the Education Ministry (2013), from projected school-age SWDs are 363,800 children, 106,274 children attended primary, special and inclusive schools, and 23,347 children attended junior special and inclusive schools. Thus, those who have not received the right to education still have 234,179 SWDs. High prevalence is not supported by sufficient knowledge of the role, parenting, and excellent support of parents at home so that SWDs in inclusive schools should receive intensive attention and appropriate handling of teachers in schools. Puji (Head of the Inclusive Education Section of the Provincial Education Authorities of East Java) explained that one of the efforts of the government is providing training three times a year for inclusive school educators (private interview, December 9, 2014) for supporting them become professional, inclusive teachers.

The results of a brief interview conducted on several elementary school teachers in East Java in an Inclusive Education workshop at the Sun City Sidoarjo Hotel on November 9, 2014, found that in general primary school teachers found it difficult to handle SWDs in the inclusive schools where they served. Also, this program is quite new among the primary education levels universities are also considered insufficient to provide insights for an educator, when they were 
studied at the college, related to four teacher competencies, especially pedagogic competence in an inclusive setting. Puji saw this matter urgent because, in addition to pedagogic competence, prospective educators also should have teaching experience in inclusive settings, as has been done by some other developed countries such as Japan, UK, America and Australia (personal interview, December 9, 2014).

Choosing the SDN Inclusive KlampisNgasem 1 Surabaya as the research place is because this school is the best inclusive school in Surabaya and it has biggest SWDs population. Researchers want to prove whether these positive achievements align with the quality of teachers and students. As well as the negative facts found so far related to the readiness of primary school teachers in implementing inclusive education can be rebutted by the real condition of the portrait to be performed on SDN KlampisNgasem 1 Surabaya. Besides, this research is also intended to know the efforts of the universities in equipping prospective educators in all aspects to then employ in inclusive schools. Because the primary school is a place for establishing the first major foundation young generation, therefore it becomes a necessity to provide proper education by competent teachers. Then, education for all without discrimination can be applied in Indonesian educational setting. This is because all the children without seeing the physical, mental, or intellectual limitations have equal rights to education. That is what will be described in a study entitled "Teacher Pedagogic Competencies for SWDs in Inclusive Elementary Schools."

\section{METHODS}

This study used a qualitative approach with a descriptive method which describes the pedagogic competence of teachers for SWDs by considering the characteristics and severity of disability in each inclusive class at SDN KlampisNgasem 1 Surabaya. Researchers used three types of qualitative research: document or text study, observation, and semi-structured interviews. To do the observation, the researcher involves the active learning activities. The informants of the research consist of four categories. Category 1 is two class teachers, and category 2 is two subject teachers. Data collection techniques used are through classroom observation, semi-structured interview and documentation evaluation (analysis). This research was conducted at SDN KlampisNgasem 1 Surabaya for approximately two months. Data analysis used is data reduction, data presentation, and creating a conclusion. In strengthening the validity of data that have been obtained, researcher use source triangulation that is by interviewing the headmaster as superior who give duty, other teachers as the co-worker, and students as being led.

\section{FINDING AND DISCUSSIONS}

\section{Finding}

In conducting the analysis, the informants in this study are grouped into two categories, namely: category 1: two informants who work as homeroom teachers in II and VI grades. Category 2: two informants who work as subject teachers of English and Physical education.

The informants in this research are professional teachers at SDN KlampisNgasem 1 Surabaya. A semi-structured interview based on informant's experience during teaching and assisting SWDs at SDN KlampisNgasem 1. The results of this interview are then grouped based on ten aspects of teachers pedagogic competencies described in Permendiknas No.16 of 2007. The results of this study are also based on the analysis of lesson plan made by informants. The analysis is based on four main components in developing the lesson plan for inclusive schools based on the inclusion education module that is objectives, content, processes, and evaluation. The objective is competence to be achieved after the students complete the 
educational program within a specified period. The purpose of education ,in general, is divided into three types of abilities namely: (1) cognitive, (2) affective, and (3) psychomotor. Content is the material that must be learned by students to achieve the goals. The process is an activity that will be undertaken by the students. Therefore, they can master the material taught and accomplish the learning objectives that have been set. Evaluation is a process of activities conducted to determine the level of success/achievement of educational goals that have been set.

\section{DISCUSSIONS}

Pedagogic competence which is the essence of this learning process could enhance students' academic performance, self-development through extracurricular activities, and socio-emotional development that can be seen from the interaction, communication, and socialization of the SWDs with their surroundings. Then it is clearly explained in the inclusive education, training module (2010) that three of the five major components to be considered in the inclusive schools are (1) teachers must apply interactive learning, (2) teachers are required to collaborate with other teachers or resources in planning, implementation and evaluation, (3) teachers are required to involve parents significantly in the education process. This is what Hamalik (2010) states explicitly in his writing that teachers are key to the learning process in the classroom. In line with Uno \&Mohamad (2014) that the teacher position on KBM is very strategic and deciding, this is implicitly on the centralized interview, participant observations, documentation study's that has been proven its legitimacy through triangulation sources toward four informants. There is a teacher from class IIA with a background as bachelor of Indonesian linguistics, having students with physically disabled, a teacher from class VIB with a background as bachelor of elementary education, having students with autism and slow learner, a teacher from English with background as bachelor of English education, then a sport teacher with a background as bachelor of sport education.

Teacher's Pedagogical competence is determined by 10 aspects based on Permendiknas no. 16 the year 2007:

\section{Possessions of Students' Characteristics Involving Physical, Moral, Social, Cultural, Emotional and Intellectual}

According to the way teachers of doing their initial assessment, it is meant to know students characteristics, types, and level of their disabilities. Then an initial assessment is also involving an interview with parents to earn a snapshot of the intellectual and emotional of children. Therefore, it can gauge and know the proper management and curriculum development. According to the result of the centralized interview, participant observations, and study's documentation toward our four informants, the responsibility of teachers, in fact, it is consistent with high competency to take care children with special needs. The more often teacher meets their students, the more saturated they are of planning the learning process and tools. It can be seen from the basic one, to identify the starter module for learning process according to what is students' need. There are only two teachers that utilize the evaluation materials as the starting point. Contradictory for those who just meet their children once a week. Hereby, they are seen incompetent of using the assessment results to identify the starter module for children with special needs in inclusive class and guidance class.

A big responsibility and the high intensity of teachers of doing the learning process in inclusive schools can be indicated and ensure the competency of the teachers have, especially in capability aspects of controlling the student's characteristics from the physical aspect, moral, social, cultural, to intellectual aspects. Results from the understanding of teachers onto the student's characteristics will have a significant impact into the quality of the learning process because in doing education, teachers will have identified their module first, and adjust what students need and characteristics. According to Sumantri and Syaodih (2006), the result of the learning process will have a good quality due to facilitating and 
coaching that teachers do, accordance to characteristics, talents, and skills of many students.

\section{Capability for Learning Theory and the Attractive Principles of Learning Process}

Start with the understanding of the students about the manner and inclusive education can give an idea of learning, motivation, and decision for learning strategy. They are included on aspects of capability for learning theory and the attractive principles of the learning process. Founded that teachers background also influences what do teachers strategic plan in the learning process. For teachers who have frequent meetings, for instance, everyday tend to have a great innovation in their strategy. Meanwhile, the infrequently teacher will be monotonous.

Results from documentation, study also show that the RPP from, what do teachers formulate is not related to the implementation. It can be inferred from the major/subject teachers who don't have enough competencies while compared homeroom teachers. As explained clearly in Kurikulum Tingkat Satuan Pendidikan (KTSP) in Uno \& Mohamad (2014), the position of teachers on Learning process is very strategic and deciding. Strategic is because teachers decide how depth and width the materials for learning and Deciding means teachers are the only one who can choose and pick what the contents, modules that will be delivered in the class. This is the key point that should be known by teachers in doing their duties so that there is a fundamental point used to formulate and develop the learning activity. Then it has been teacher's responsibility to understand the theory and the basic principles of the appropriate learning process, do not cross the line that has been agreed universally.

\section{The Capability on Developing the Curriculum}

The capability of developing the curriculum which relates to the development is not only implicitly but also explicitly. Facts that have been founded are the teachers who seem the lesson plan as the guidelines on learning process view lesson plan as merely a formality and emphasize the practice. It can be seen if only two from four informants use lesson plan regular in inclusive education. It is apparently not in line with the six principles of inclusive curriculum development which have been stated in the training and education module for inclusive (Budiyanto, 2012), one of them is about the general curriculum, it has been applied to regular students, then it needs to be changed or adjusted for students with special needs. The teachers who rely on the lesson plan that is formulated together with KKG also do not see SWDs on formulating the learning process, and it will have an impact on imperfect implementation.

It is known that the experience and duration of teaching in inclusive schools do not align to the high competence of teachers in developing curriculum. Teachers who have much experience in the inclusive education system should be better in planning and implementation. A teacher who does not have a special education background and only has one year experience managing SWDs in inclusive school can develop and implement her learning plans well. This is because she has

21 years teaching experience in regular schools for 21 years which affect her ability. This teaching experience also encourages her to stick with her duties as a teacher, which can be adaptable in any educational context including the inclusive school system. In contrast to the teacher who has more than 12 years of inclusive teaching experience is not accompanied by the fulfillment of key tasks in inclusive school. Therefore, he is considered less competent in serving the needs of SWDs. It can be indicated that what teachers need in this aspect is the understanding that in inclusive education teachers should be able to develop curriculum models because the needs, characteristics, and abilities of SWDs cannot be equated with regular children. Particularly for those with severe disabilities. Therefore adjustments through the development of the curriculum model are needed to make the teachers can accommodate SWDs learning needs equally. 


\section{Organizing Educated Activities}

This competence is done well in SDN Klampis Ngasem 1 Surabaya, which proved by the effort to apply academic and non-academic activities routinely in the school. Based on the results of semi-structured interviews conducted by the researcher, the four informants explained that they centralized the educated development on the academic activities in the classroom. The real action is to raise the learning spirit and achievement of the student through giving rewards in the learning process in the form of praise, motivation, and positive affirmations to the children. Three of four informants stated that the rewards in the form of goods are less useful for children. Another teacher as a teaching partner of four informants acknowledged that the all the informants developed the learning activities in the classroom by applying the effectiveness of using rewards. The impact of rewards application in the class can increase the spirit of the students, and it can appreciate the children especially SWDs in term of their learning development. The reward method is a definite reinforcement form according to behaviorism theory. Behaviorism theory stated that a change in behavior is a result of the interaction of stimulus and response (Ningsih, 2005). The reward can be interpreted as a reinforcement of the learners' behavior. Reinforcement is the use of consequences for behavior (Woolfolk, 2008). It means that a behavior performed by learners and considered appropriate. then followed by reinforcement. The use of rewards raises the desire of the learner to do good things continuously. Reward, in this case, becomes very important as one of the external motivation used to strengthen student behavior especially SWDs. Therefore, the learning process can be done competitively and actively.

\section{Conducting Educational Development Activities is in Line with the Facilitation Aspect of Developing the Learners' Ability}

The aspect of conducting educational development activities is in line with the facilitation aspect of developing the learners' ability. The four informants give the same statement that this aspect is filled with the implementation of extracurricular activities every Saturday. But it is not directly arranged by them, but through other trainers. It states that there is no contribution of the four informants in the educational development activities of children through extracurricular activities. SWDs who are often being underestimated is the human being who has the same right to maximize their ability. By Anita Woolfolk (2008) that outstanding students are students who have significant skills or problems that require special education or other services to achieve its potential. Additional services can undertake to assist students in developing their potentials are through extracurricular activities and compensatory services which directly guided by the teachers. The four informants provided the same understanding that for SWDs compensatory services were developed in the source room (special class), whereas based on the observation showed that SWDs were studying in full inclusive class like grade IIA and VIB no longer entering the special class. Therefore, they did not get the compensatory service. The number of rotational teachers who used to be placed in non-inclusive schools made the teacher lack understanding utilizing compensatory service. On the other hand, the trainers for extracurricular activities are recruited separately who professionals in the field.

It can be indicated that homeroom teachers and subject teachers as educators insufficient to develop and actualize learners' ability. This becomes an input for the education ministry, teachers education institutions, and principals to equip the ability of teachers in carrying out educational development activities through extracurricular activities and compensatory services training for teachers inattention to accommodate the talents and potentials of students especially SWDs. Based on the interviews results and classroom observation, it was found to be directly proportional. 


\section{The use of Information and Communication Technology (ICT) for the Purpose of Organizing Educational Development Activities}

The three informants expressed the use of information and communication technology (ICT) to organize educational development activities, but the reconstruction of the school causing the transfer and incorporation of the class which makes the using of ICT ineffective.

Teachers who initially use it because it feels effective for teaching and learning activities should be stopped for a moment because the tool is secured in storage during the school reconstruction. While one informant as a sports teacher admitted that he utilized the use of ICT only in the learning preparation process at home. This is because the physical education focuses on field demonstration activities. Therefore ICT usage is less than concrete learning media. It is known that the four teachers have met the pedagogic competence on aspects of utilization of ICT for the benefit of organizing educational development activities. Interviews with students, colleagues, and headmaster explained the same thing that the use of technology at SDN KlampisNgasem 1 is going well and smoothly, students can feel the benefits of ICT either visual or audiovisual. In line with the theory stated in government regulation number 74 2008, that teachers who can utilize ICT well will help and facilitate them in preparing teaching materials, therefore the teachers' skills can be formed well.

\section{Communicate Effectively, Empathically and Courteously with Learners}

Communication as a means of language in life plays a pivotal role between teachers and students in carrying out teaching and learning activities. Communicate effectively, empathically and courteously with learners, apparently continued to be done by the four informants in this study. Their empathic form of SWDs makes communication among them wellformed. A statement from informants found that communication formed not only in formal teaching activities in the classroom, but also in informal teaching activities when the teachers communicate merely but have a good impact on the students. The means of communication is also used by informants in motivating and advising children. Therefore, it is known that the four informants have met the competence to communicate effectively, empathically and courteously with the students. It is from this communication relationship that SWDs begin to establish socialization and interaction with other regular students, which is only available in the inclusive education system. SWDs incorporated in regular educational containers have the hope of removing the gap between SWDs and regular students while creating education for all without discrimination. Obviously, it can be realized if the educator has good pedagogic competence. Following the opinion of Irina and Liliana (2011) in his scientific journals that the pedagogic competence of the teacher is closely related to three important factors namely learning achievement, self-development, and social change. These are the three aspects that will shape the child in the shelter of inclusive schools. Inclusive schools will increase the self-esteem of children with special needs because they are not alienated from their surroundings as if they were placed in special schools or classes, and this has been done quite well in SDN KlampisNgasem 1 Surabaya. Based on the results of interviews and observation, the researcher found positive activity among the school community with the SWDs although in the implementation SDN KlampisNgasem still held a special class implementation. This is because SWDs have a severe disability, it happens in Down syndrome, autism, and deaf students.

The same thing is described by (Delphie, 2006), that in addressing the students with special needs, especially those who bear developmental, mental disorders, teachers are expected to provide more tangible reinforcement in the effort to establish the performance of learners. For instance, in the teaching and learning process in the classroom, teachers accommodate SWDs with a warm touch and two-way communication. When the teacher has been able to do the tangible 
reinforcement, automatically the student's performance will be formed by itself. The performance is integrated between SWDs with other regular students, then social interaction and socialization SWDs can be optimized well.

\section{Competence of Conducting Assessment and Evaluation of Process and Learning Outcomes}

Competence of conducting assessment and evaluation of process and learning outcomes, shown by the teacher through two ways that are in concept and implementation. Based on the results of interviews it is known that the teacher evaluates the children, according to the needs of SWDs, but the result of the documentation analysis, the researcher found two informants as the subject teachers did not provide the evaluation process based on the needs and the characteristics of SWDs in the lesson plan.

The evaluation should be done according to the characteristics of the learners, in fact, based on the evaluation sheet applied to the regular students. After the observation, the fact appears that teachers who are based on non-inclusion evaluation are not maximized in the learning evaluation process because the evaluation rubric used is different from the evaluation rubric they have designed in the lesson plan. Further, teacher's ability is known from the way they utilize the assessment results. Utilizing the assessment results are seen from the way informants using it to improve the ability and condition of the students especially SWDs. This is further embedded in the follow-up plan (RTL) which formulates by the teachers in the lesson plan.

\section{Utilizing the Results of the Assessment}

In a semi-structured interview, the four informants claimed were designing the RTL is a process of utilizing the results of the assessment, but based on the analysis of the lesson plan, it was found that only two informants as homeroom teachers provide the RTL in their lesson plan. Two other informants did it separately in their records (notes) without designing them into the lesson plan. This is seen as a rule error in implementing the lesson plan. The RTL should be stated in a lesson plan and then developed following the real results obtained after the lesson is run. From the present invention, it is known that two other informants have not mastered the competence of utilizing the assessment results.

The use of the assessment results refers to the evaluation results that have the following specific objectives, (a) to stimulate the activities of learners in the education process, (b) to discover the factors of success and non-success of learners in the education process, in attention to find a way out (Sudijono, 2012). This is the basis of teachers in creating and implementing follow-up plans for students. If students have fulfilled the learning objectives, then students can continue to the next learning, but if students do not meet the learning objectives, then the teacher must apply remedy (repetition) of lessons to complete the learning objectives have not been well fulfilled by the students. These components are contained in the RTL which must be understood correctly by educators to prevent mislead in designing and implementing RTL for students. The four informants have done well. More than that, communication activities to parents, related to the development of SWDs in schools are also well established.

\section{Taking Reflective Action to Improve the Quality of Learning}

Taking reflective action to improve the quality of learning has been met well from the four informants, but for the informants of subject teachers, the intensity of communication with parents is not as much as the classroom teachers who keep abreast of and meet with the SWDs every day. Based on the results of observation shows that parents are more actively communicate with classroom teachers during break time and when picking his son home from school. The results of interviews with students also showed that these four informants always do reflective actions such as questioning at the end 
of the learning. The discussion (question and answer) that was conducted remained within the limits of the material taught on that day to check students' understanding of what they have done together with the teacher. Clarified by the opinion of Ruhimat (2007) that the final activity of learning is not only interpreted as closing the learning activities, but more to know the students' mastery of the competence that is expected. By doing, so teachers are expected to know the competencies that have or have not mastered by the students. This activity usually revisiting student mastery and giving the test, both orally and writing (assessment).

Studying SWDs in inclusive schools is the right thing to do in shaping and improving a friendly, open, dominant, and independent person. SWDs with their potential able to learn to interact, socialize and communicate in a replica of normal life in the school environment. The characteristics and needs of different SWDs, making the initial and outcomes highly dependent on several factors, one of it is the teacher who handles them with good pedagogical competence in delivering SWDs toward significant growth. The components of human resources in inclusive schools such as classroom teachers and subject teachers are unity to form a friendly, open, dominant, and independent person.

Apart from the weaknesses of the subject teachers and the strengths that the classroom teachers have in handling SWDs, that is the process of improvement that must be continued by both categories of informants in this study. Because of the results of the research, it is known that for the one (1) category, the IIA and VIB class teachers meet nine (9) out of ten (10) aspects of pedagogic competence and for category two (2) English and PE teachers only fulfilling four (4) out of ten (10) aspects of pedagogical competence according to Permendiknas no.16 of 2007.

From the overall research, the result implies that the graduate of primary school teacher education guarantees the fulfillment of teacher pedagogic competence when plunged in the real work field. This is because while studying in college is also equipped with adequate inclusive knowledge, not just the fulfillment of the theory, but also with the fulfillment of observation activities and field studies in the form of internships applied to students as prospective educators. It proves that primary education department graduates are needed in the job field, of course, the graduates who are able mastering the pedagogic competence well. This is because PeraturanPemerintah No. 19 of 2005 on National Education Standards article 28 (3) states that the competence that must be possessed by a teacher as a learning agent one of them is pedagogic competence which is the ability to manage learning process, including understanding of learners, design, and implementation of learning engagement, evaluation of learning results, and development of learners to actualize their various abilities.

This is then the input for the primary education department continues to equip prospective educators in the university with the inclusive knowledge, especially pedagogic competence indicators, develop the inclusive education studies as a compulsory subject which are not only fixated on the introduction of SWDs characteristics, but further ways in handling, educating, and serve SWDs with their respective disorders. From ten aspects of teacher pedagogic competence which becomes the basis of this research, the aspect that cannot be fulfilled by the four informants is to facilitate and actualize the various of learners abilities through extracurricular activities and compensatory services. It also needs to get the attention of the primary education department to be able to develop better the provision of extracurricular activities and compensatory services for prospective educators, not only for knowing but also for doing well. Therefore, in the future it can be applied to learners in real work environment, and also provide provision for educator candidates to find out how to fulfill the rights of inclusive learners in the effort to implement education for all, education that not only focuses on regular students but also implements fair and equitable education for all learners without prejudice to the rights of SWDs and regular 
students. Primary education departments who have authority in this regard are also expected to apply real working practices in inclusive schools for prospective educators. For the theoretical science (knowledge) that has been given can be deepened and developed through real experience when the plunge in the field. Therefore, the prospective educators not only sharpen their intellectual, but also can form their emotional and spiritual intelligence through direct contact with SWDs.

In the results of this study also implies that the competencies possessed by graduates Primary education department better than pedagogic competence educator non-Primary education department. The Primary education department (PGSD) as an educational institution has demonstrated its commitment in preparing qualified graduates with the provision of primary education even with the provision of inclusion. This is why the right person who is placed in the inclusive primary school are the educators who have the capability in the field. From the results of this study, the researcher can prove the theory of OemarHamalik (2010) which states that the professional competence of teachers other than based on one's talents, and teaching experience, also based on the educational background of the teachers which plays a pivotal role. In this case, the pedagogic competencies of teachers which is one of the four professional competencies of teachers can be learned or prepared by a person through the process of teacher education. Primary teacher education in Indonesia is handled by Manpower Providers namely Pendidikan Guru SekolahDasar (PGSD), and Titin has fulfilled that. Eight years of teaching and becoming a junior teacher at SDN KlampisNgasem 1 Surabaya shows her competence that is directly proportional to his educational background as a graduate of PGSD. This proves that with his youthful spirit she demonstrates superior competence in the success of inclusive education especially in the largest inclusive environment in Surabaya, SDN KlampisNgasem 1 Surabaya. Further, there is also a teaching experience that can form teacher pedagogic competence, and this is under the theory presented by Suyitno (1997) that a teacher who has a lot of experience in teaching will be easy in implementing quality teaching and learning process.

In line with the work experience of Purwati as a senior teacher with 21 years of teaching experience can prove his seriousness in developing education sector of Indonesia. She provides quality and loyalty in accordance with the education system where not always senior teachers with high enough work experience can show their competence well. But based on the results of observation and interviews shows Purwati able to prove teaching experience in line with pedagogic competence she has. It happens because Purwati can take advantage of his time by attending training activities or workshops to increase the competence of teachers to update her knowledge and abilities, thereby affecting the increase of abilities she has. Besides, Purwati also has the high willingness, passion, love and empathic towards the students in particular SWDs. These what make her being encouraged in the age that is not young anymore in providing the best quality of learning for learners.

Another interesting finding indicates that the teacher who just started his experience in teaching will be easy in implementing the quality of learning engagements. This is viewed from the knowledge that is still fresh and has contemporary elements. Therefore, it will be straightforward in implementing creative learning by the needs of children. Ways of handling the students also will be easy because the age is not far away. Therefore the teacher can create a good relationship with students without certain gaps. Of these things are known the results of this study proved related theories and new findings of the competence of teachers. It is realized that in the effort to educate SWDs either cognitive, affective, or psychomotor aspect needs teamwork from all parties not only homeroom teachers, but also good cooperation with all stakeholders including SWDs parents who play a leading role in the family environment. 


\section{CONCLUSIONS}

Teacher pedagogic competence as used in this research can find out to what extent the inclusive teachers have pedagogic competence indicators that become the basis for teaching and learning process, especially for SWDs. Based on the overall research results that refer to the 10 aspects of pedagogical competence of teachers, according to Permendiknas no.16 of 2007 can be concluded that the teacher with category one (1) meets nine out of ten aspects of teacher pedagogic competence and for category two (2) only meets four out of ten aspects teacher pedagogic competence. The results of this study imply that category one which is primary education graduate and a senior teacher with high work experience can prove the theory that the professional competence of the teacher, besides based on the teacher's talent in a person, the teaching experience, also based on teacher educational background. This is then the responsibility of teachers in cooperation with the stakeholders, namely Dispendik Surabaya and the primary education department to continue improving the competence of teachers, especially in primary education level. This is because the pedagogic competence of teachers is a fundamental thing that must be owned by educators in applying the learning activities by the characteristics of students, friendly and open for both SWDs and regular students. Because the purpose of this inclusive education is not only to provide extensive opportunities in term of communication, socialization, and interaction for SWDs but also to provide meaningful learning for regular students to respect, appreciate and accept the existence and condition of SWDs as school members in a form the beauty of diversity.

\section{Acknowledgement}

On this auspicious occasion, the researcher would like to express her highest graduate to Indonesia Endowment Fund for Education (LPDP) as institution giving fund to learn in graduate level at Tsukuba University.

\section{REFERENCES}

1. Budiyanto. (2012). Modul Pelatihan Pendidikan Inklusif. Jakarta: Kementerian Pendidikan dan Kebudayaan Direktorat Jenderal Pendidikan Dasar.

2. Delphie, B. (2006). Pembelajaran Anak Berkebutuhan Khusus dalam Setting Inklusi. Bandung: Refika Aditama

3. Departemen Pendidikan Nasional Republik Indonesia. (2003). Undang-Undang Republik Indonesia Nomor 20 Tahun 2003 tentang Sistem Pendidikan Nasional. Jakarta: Biro Hukum dan Organisasi Sekretariat Jendral Departemen Pendidikan Nasional.

4. Departemen Pendidikan Nasional Republik Indonesia. (2004). Standar Kompetensi Guru Sekolah Dasar. Depdiknas Dirjen Dikdasmen Wahab, Abdul dan Lestari, Lies Amin. 1999. Menulis Karya Ilmiah. Surabaya: Airlangga University Press.

5. Departemen Pendidikan Nasional Republik Indonesia. (2005). Undang-Undang Republik Indonesia Nomor 14 Tahun 2005 tentang Sistem Pendidikan Nasional. Jakarta: Biro Hukum dan Organisasi Sekretariat Jendral Departemen Pendidikan Nasional.

6. Departemen Pendidikan Nasional Republik Indonesia. (2005). Peraturan Pemerintah Nomor 19 Tahun 2005 tentang Standar Nasional Pendidikan. Jakarta: Biro Hukum dan Organisasi Sekretariat Jendral Departemen Pendidikan Nasional.

7. Blessing, Anumaka Ijeoma, Sol Sofia, and Co Obonyo. "An Examination of Pedagogical, Andragogical Approaches in Educating Visually Impaired Learners in Special Schools and Vocational Centres Rarieda, in Siaya County Kenya." 
8. Departemen Pendidikan Nasional Republik Indonesia. (2007). Peraturan Menteri Pendidikan Nasional Nomor 16 tahun 2007 tentang Standar Kompetensi Guru. Jakarta: Biro Hukum dan Organisasi Sekretariat Jendral Departemen Pendidikan Nasional.

9. Departemen Pendidikan Nasional Republik Indonesia. (2008). Peraturan Pemerintah Nomor 74 Tahun 2008 tentang Standar Kompetensi Guru. Jakarta: Biro Hukum dan Organisasi Sekretariat Jendral Departemen Pendidikan Nasional.

10. Hamalik, O. (2010). Psikologi Belajar \& Mengajar. Bandung : Sinar baru algensindo.

11. Irina, A \& Liliana. (2011). Pedagogical Competences - The Key to Efficient Education, International Online Journal of Educational Sciences. Vol. 3. No. 2, 411-423.

12. Ningsih, A. (2005). Belajar dan Pembelajaran. Jakarta: Rineka Cipta

13. Ruhimat, T. (2007). Kurikulum dan Pembelajaran. Jakarta: Rajawali Pers

14. Sudijono, A. (2012). Pengantar Evaluasi Pendidikan. Jakarta: Raja Grafindo

15. Sumantri, M \&Syaodih, N. (2006). Perkembangan Peserta Didik. Jakarta: Universitas Terbuka

16. Suyitno, A. (1997). Dasar-dasar Proses Pembelajaran Matematika I. Semarang: Jurusan Pendidikan Matematika. F MIPA UNNES.

17. Uno, H. B\& Mohamad, N. (2014). Belajar dengan Pendekatan PAILKEM. Jakrta. Bumi Aksara

18. Woolfolk, A. (2008). Educational Psychology Active Learning Edition. Tenth Edition. Boston: Pearson Education. 